Article

\title{
Co-Design and the Collective Creativity Processes in Care Systems and Places
}

\author{
Cristian Campagnaro *, Nicolò Di Prima and Sara Ceraolo \\ Department of Architecture and Design, Politecnico di Torino, Italy; E-Mails: cristian.campagnaro@polito.it (C.C.), \\ nicolo.diprima@polito.it (N.D.P.), sara.ceraolo@gmail.com (S.C.) \\ * Corresponding author
}

Submitted: 10 May 2021 | Accepted: 13 September 2021 | Published: 30 November 2021

\begin{abstract}
This article examines the topic of participatory design processes (co-design, co-creativity, co-creation, and co-production) as tools to promote models of inclusion that benefit people experiencing marginality, and as means to solicit the public dimension of the spaces in which they live and where they have access to their health and welfare services. The topic is addressed through four case studies drawn from the experience of participatory action research aiming at social inclusion and cohesion through an approach based on design anthropology. Following Jones and VanPatter's (2009) four design domains (DD), the projects discussed in this article are the following: participatory design of devices for people with multiple sclerosis (DD 1.0); participatory renovation of shelters for homeless people (DD 2.0); design and craft led lab aiming at social inclusion (DD 3.0); and innovation of public services for a city homeless population (DD 4.0). All these projects are driven by stakeholders' demands for a transformation that improves the quality of users' lives, the quality of caring services, and that they modify, temporarily or permanently, the venues where they take place. In order to support and facilitate this "desire for change," the projects are based on wide participation and collaboration between many different stakeholders in every phase of their design processes. Methods, tools, and results will be analysed from the points of view of both users (beneficiaries and social operators/caregivers) and designers. Furthermore, the interaction between spaces, co-design processes, and attendees will be investigated to determine how they contribute to turning those venues into citizenship environments, permeated with greater care and attention.
\end{abstract}

\section{Keywords}

beauty; caring spaces; co-creation; co-design; participation; vulnerability

\section{Issue}

This article is part of the issue "Art and Design for Social Inclusion in the Public Sphere" edited by Karin Hannes (KU Leuven, Belgium).

(C) 2021 by the authors; licensee Cogitatio (Lisbon, Portugal). This article is licensed under a Creative Commons Attribution 4.0 International License (CC BY).

\section{Introduction}

As a research group of designers, anthropologists, and sociologists, we have been experimenting with participatory projects and inclusive social models since 2009, addressing, among others, issues such as housing, access to food, health, and independent living, citizen participation, and social cohesion (Campagnaro, 2021b; Campagnaro \& Ceraolo, 2020; Campagnaro \& Di Prima, 2018a; Campagnaro et al., 2021; Campagnaro,
Porcellana, et al., 2018; Passaro et al., 2021; Porcellana \& Campagnaro, 2018, 2019a). These issues often remain unsolved for some categories of citizens that are in a condition of fragility and have to do with the dignity and enforceability of fundamental individual rights. If neglected, these issues end up fostering forms of marginality, significantly affecting the functioning of such individuals within society (Magni, 2006, pp. 18-21), their abilities, as well as their very freedom to act (Magni, 2006, pp. 49-54; Sen, 2008). 
Our action research led according to both a participatory (Mclntyre, 2008) and a design anthropology approach (Gunn \& Donovan, 2012; Porcellana \& Campagnaro, 2019b; Porcellana et al., 2017, 2020), has a transformative attitude and it places the individuals at the centre of the project. It also enhances their abilities and skills within a network of further resources and competences of which they can take advantage. For the benefit of these human resources, and starting from them, processes of creativity, self-promotion, and citizenship are activated in people's environments to combat the conditions of social exclusion and the further issues connected with it. This article aims to debate these participatory design processes, for how they exploit collective creativity, co-creation, and co-production to promote models of inclusion to cater for the needs of people in marginality (Nota \& Soresi, 2017; The Care Collective, 2020) and to strengthen the public dimension of the spaces where these processes take place. We will investigate them via four case studies drawn from the experience of our action research, which we have carried out in several Italian cities: We design together with people in marginality, front line workers, caregivers, service managers, and will focus both on methodological analysis and on the transformations implemented.

The cases discussed here involved citizens with disabilities, immigrants, and experiencing homelessness, through design processes, carried out right in the venues they live and where they access health and welfare services. Those citizens are often regarded as fragile persons since they manifest urgent and highly impacting needs that require specific answers that are usually provided by multiple services. They are regarded as "marginal" citizens because they do not correspond to the "average citizen" due to the different way they participate in collective life-both of Arnstein's (2019) nonparticipation and tokenism degrees of participationand due to the greater difficulty they have in exercising their rights. As already stated, the beneficiaries' needs, which are addressed through our projects (for housing, food security, physical and psychological wellbeing, poverty, job, training, social relationships, independent living) are multidimensional (Brandolini et al., 2009) and interlinked.

In our experience, the services often appeared too weakly structured to meet this multidimensionality of social exclusion, rooted in material, personal, and social discomfort. To our eyes, services seem like they have to be ever-changing entities that need to be constantly transformed to provide the better answer to meet everchanging and complex social needs.

The projects under discussion here are driven by stakeholders' demands for a transformation, whether or not of a tangible kind, that improves the quality of users' lives, the quality of caring services, as well as their environments. The expected changes arise from differentiated levels of a participatory design intervention which aim to develop devices for those with reduced mobil- ity, redesign housing spaces and housing-related spaces, strengthen community-led inclusion processes, and promote innovation of city services for homeless people toward personal wellbeing and enhancement of the individual's life.

We propose two driving hypotheses. The first one is that designing with and for fragile people means taking care of the whole society by beginning with the poorest; it also means strengthening support and protection networks for every citizen to reduce disparities and disadvantages, as well as fostering relationships, shared values, and feelings of belonging. The second hypothesis is that the very openness of places, which is key in the processes of public care, also depends on the encounters and the links that are created by collaborative and collective creativity. They turn out improved by these design processes, more welcoming, and cognitively and ergonomically accessible.

\section{Method and Tools}

The disciplinary context of our action research refers to the experience of the so-called design for social innovation (Manzini, 2015) and social impact design (Smithsonian Institute, 2013). These locutions describe two dimensions of the act of designing for people: The first one relates to the nature of the needs to which design is called to respond; the second refers to the transformations needed to satisfy those social needs. They link to several definitions (e.g., design for good, socially responsible design, design for social change, public interest design, etc) each of which contributes to highlighting the methodological richness and complexity of the operational field of social impact design. All of them synthesise the themes of commitment to individual and social fragility, the centrality of the human dimension and its capacities, and remain attentive to the dignity of all individuals. Besides, they all renew the fundamentals with which Dreyfuss (1955), Papanek (1971), and Schumacher (1973), about 50 years ago, outlined as the mandates of socially responsible design.

Consistently with this premise, the fundamental principles of our interdisciplinary and multidimensional approach to complex social systems are the following:

1. We aim to investigate the context as a complex system of people, sequences of actions, flows of information, organisational roles, and individuals' moods and behaviours. We are persuaded that "no genuine transformation in ways of thinking and feeling is possible that is not grounded in close and attentive observation" (Ingold, 2013, p. 4); thus, the interactions among beneficiaries and among stakeholders as well as how they use and perceive spaces, tools, and objects are object of our field study. To do so, we apply qualitative analysis tools from both anthropological and co-design research, such as focus-groups, 
in-depth interviews, video tours, participant observations (Ingold, 2013, pp. 4-6), system mapping, and boundary objects (Carlile, 2002; Star, 2010). Also, the design project (by means of tangible and low-resolution prototyping processes; see Brause, 2014; Hillgren et al., 2011; Meroni et al., 2018) is a tool we use to understand the system in all its complexity, including the barriers to the pursued change.

2. To co-design processes, rules, tools, and artifacts, all the actors are involved as expert users; all of them have a voice and bring their daily experiences, by participating as "diffuse designers" (Manzini, 2015). According to a model of participatory action research, we-researchers, designers, participants, and beneficiaries-share decisionmaking processes, we design the vision of change together, and together produce the knowledge on which we agree.

3. We encourage co-production. All the stakeholders are invited to make their time, resources, and their networks available to sustain and foster the design initiatives based on a vision of co-ownership and shared responsibility.

4. We conduct co-creation processes. During the most tangible and practical stages of the project, we enable all attendees to take part in building the artifacts, to concretely contribute to tangible transformations, and to learn from one another.

As a result, the co-design processes produce solutions nourished by the participation of the stakeholders and open for collaborative improvement and negotiation. These design solutions can be conceived as products, both tangible and intangible, and as prototypes. They are products, as they represent the final stage of the creative process that finds its formal expression in them; meanwhile, they are prototypes, as they are not pre-determined by a top-down approach, being constantly re-discussed and improved by the stakeholders in an iterative process.

The workshop is the most practical and participatory instrument we adopt to materially gather people and enable them to shape products and services dealing with the change they pursue. Our workshops entail on-site interventions working from within the context; they are extraordinary because of the time they take away from everyday life and the role inversions they promote through, and during, the creative and collaborative actions. Each workshop also stimulates synergies among the actors via the informal and dialogic environment it generates (Sennet, 2012), where solutions are discussed and performed by and with all participants; here, as Bourriaud stated (2010, pp. 13-24), the group recognise itself in them and consequently the solutions benefit from more care and attention. In this sense, all the outputs that the design process generates can also be seen as "relational goods" (Bruni, 2008), because of the relations produced by the processes and because of the stories generated by them.

We also pay close attention to the practical work. We encourage the use of simple techniques and tools that anybody can handle so we can give as many people as possible the opportunity to participate in cocreation processes. In this way, the workshop also offers the opportunity to invite as many citizens "from outside" as possible. From our perspective, practical activities are essential to involve the actors. The type of action that the process implies can vary, but it should always imply some sort of material activation and tangible engagement of the participants. The highest level of this happens during the processes of co-creation, when "do-it-yourself" activities-or, even more appropriate, "do-it-ourselves"-enable the users' participation in the social design process (Lee, 2008) and the "real design participation" happens just because users have some sort of full creative autonomy in the process (Banham, 1972).

\section{From the "Field" of Our Action Research}

\subsection{Design for Each(One): Co-Designing Personalised Devices for People With Multiple Sclerosis}

How to open the plastic film of a gelled water cup independently; how to play foosball sitting in a wheelchair, even with only one moveable hand; how to hold playing cards and how to sign with very weak hands. These are some of the everyday needs of persons with multiple sclerosis (MS) with whom we have designed. These are the design demands we addressed during the co-design workshops planned in the framework of the project Design for Each(One).

Design for Each(One) involves service users, caregivers, designers, young citizens who attend the bachelor's degree in design and communication and researchers; it promotes collaboration between our university, the Italian Association for Multiple Sclerosis (AISM) and the social cooperative Animazione Valdocco, which manages the AISM's day care service. All the above "co-designers" investigate gestures which users with MS had become unable to do and, together, we prototype small devices to facilitate those acts. During a one-week workshop of participant observation and of low-resolution prototyping (Brause, 2014; Hillgren et al., 2011; Meroni et al., 2018), through a continuous collaborative process, by using minimal material resources and very simple technologies, the aids are developed and made usable by the persons with MS.

Then, with the same method, the prototyped aids are implemented and tested (through everyday use) for a long time (6-12 months) until they are ready to be released as final products: ANTONINO allows Antonio to autonomously open the jar of gelled water with which he hydrates, no less than eight times a day. The shell of the product and its shape allow different handling modes and the toothed ring cuts the packaging film, 
allowing Antonio to remove it with a spoon (Figure 1). IT IS UP TO ME is made of cardboard; it is produced via a simple and economic paper-making process and allows users with MS to play cards autonomously even if they cannot hold them in their weak hands. FOLLOW THE LIGHT! is a laser light pointer hung on glasses to highlight letters on a ETRAN communication panel, anchored to the wheelchair; it allows Didi to share words and thoughts with less experienced ETRAN readers. Maura was again able to write her name thanks to her new aid named SIGN HERE! This wooden product was literally built around her hand and with her design contribution. Precious gestures which had been stolen by MS were regained and finally, after years, Maura was able to sign a paper.

These and other important products are key to the independent living of a person with MS and they would never have been developed according to an ordinary market-driven design approach. In fact, the needs of an individual with MS are extremely personal and specific (everyone features a progression of the disease and their own personal symptoms) and they alter continuously and swiftly. For this reason, from the mass production market's point of view, those needs are not "commercially appealing" and they would not justify economic commitment in addressing them, even if they could facilitate the daily life of users with MS.

Regarding the participation, users with MS, involved as experts, have proved able to contribute to the design with capacity and enthusiasm and to bring their "reflective voice." Furthermore, they proved to benefit from active participation in those design processes. The strong reciprocity between all the participants on concrete actions allows them to give and exchange his/her best with one another, and creates opportunities for "func- tioning" (Sen, 2008) and rules different from those imposed by the disease. Indeed, the workshop offers the persons with MS the opportunity to work around their needs in the framework of a collaborative process and for themselves to be agents of the response to their needs. From the point of view of the caregivers, as they stated during the series of in-depth interviews made over the years of collaboration, participatory processes structured around users' needs make it possible to look at everyday gestures and have a finer understanding of the person, providing an alternative and deeper understanding. Furthermore, co-design enables caregivers to cede to the users more control over their lives, toward possibilities of individual empowerment and self-determination.

Regarding the issue of the public dimension of places, in the Design For Each (one) project, we can observe how the day centre (which provides daily care and assistance [relational and health] and recreational and occupational activities for people with MS) opens up to the city and to the citizens, due to its design being shared among the several participants: It achieved a public status, which was not foreseen although it was sought out and desired by operators and organisations. In the day centre, the people with MS feel protected, at home, and able to open up to participation and interaction, more so than any other space. There, the extraordinary time of the designers meets the ordinary time of users' daily lives and those who take care of them, in the positive and non-paternalistic form of collective creativity.

\subsection{Cantiere Mambretti: Co-Designing Shelters for Immigrants and Homeless People in Milan}

The project Cantiere Mambretti (Mambretti site) deals with the participatory refurbishment of shelters for
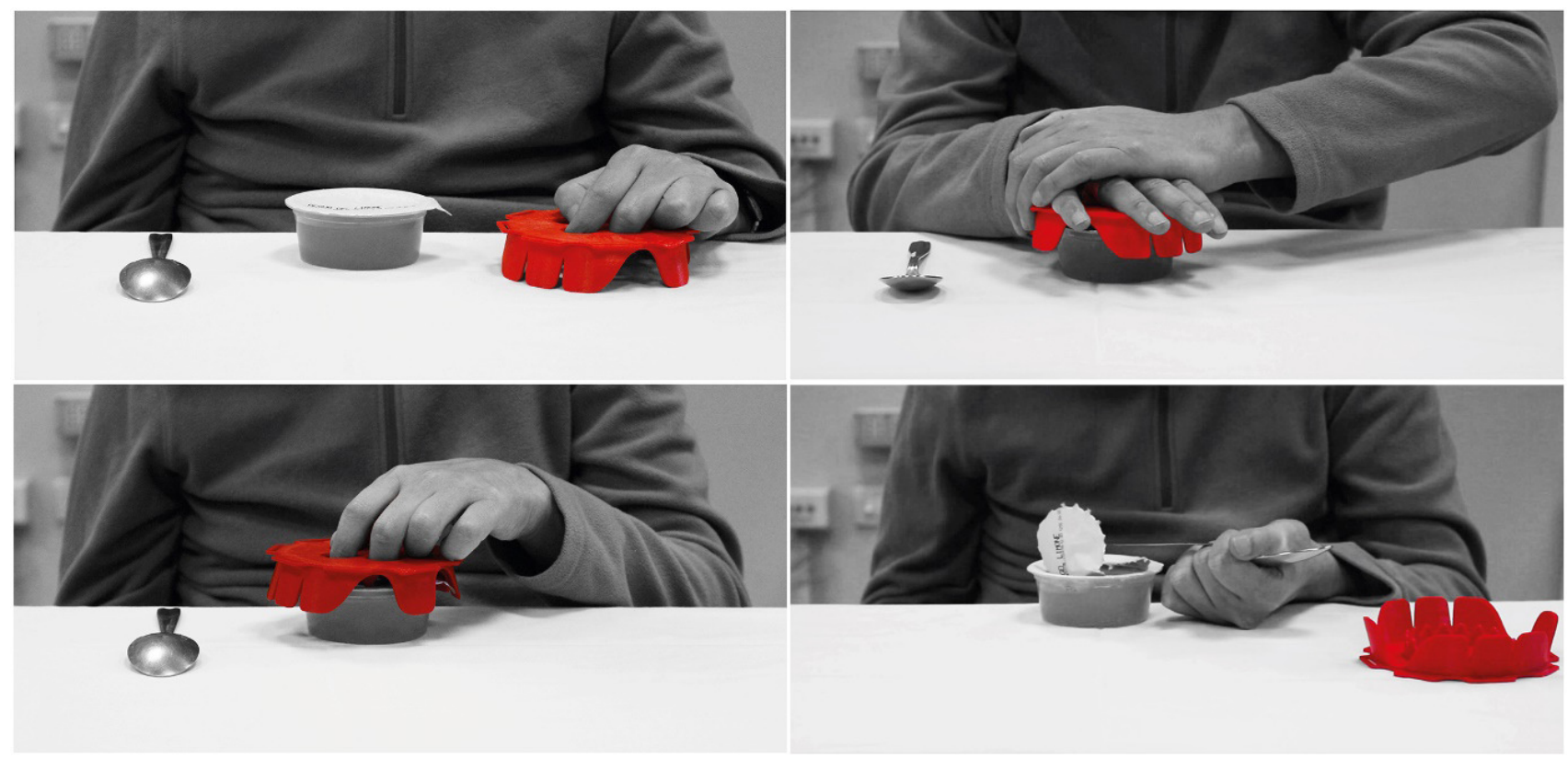

Figure 1. ANTONINO: Gestures of user who handles the co-designed device to open the plastic film of a gelled water cup. 
immigrants and homeless people, managed in Milan by Fondazione Progetto Arca. It is rooted in a wide theoretical reflection on such buildings and their improvement as environments for recovery. The aim of the project is to deal with the participatory design of low barriers and transitional shelters according to their users' psycho-emotional and social needs and to guarantee better wellbeing and inclusion (Campagnaro \& Di Prima, 2018a, 2018b). The project benefits from the practical and reflective contributions of the shelters' inhabitants and the workers from the organisation that manages the housing services. They are all involved in the role of expert users, and they cooperate with designers from the Politecnico di Torino and with citizens that attend the projects thanks to a strong social commitment.

Shelters are often hosted in buildings constructed for other specific purposes (schools, offices, factories) that, once their original function ceases, are dedicated to temporary housing purposes. Even though they are transitional and temporary solutions, they end up hosting people for a long time. These buildings are often in a state of almost complete abandonment and manifest rather serious structural problems. They also lack space for socialising and privacy, and they are equipped with low quality and second-hand furniture. Despite this, they house people who are experiencing homelessness, exclusion, poverty, and who need care and assistance. Furthermore, the spaces of the dormitories contribute to exclusion, marginality, and a sense of temporariness not only due to their physical characteristics but also because of rules, curfews, and access procedures (Campagnaro \& Di Prima, 2018b). In contrast, the design action peruses wellbeing and accessibility, and fosters a "co-created beauty" to reshape their spaces and the whole housing service delivered there, toward dignity and recognition (Campagnaro \& Giordano, 2017; Campagnaro \& Porcellana, 2016; Cockersell, 2014, p. 71; fio.PSD, 2016).

The co-design process starts with a collective exploratory tour of the venue and is driven by a cycle of focus groups and design sessions with hosts and social and care operators in order to, first, understand the critical issues to be faced, and then to agree on solutions to be developed. Then, the group takes part in the making practices, i.e., furniture building, wall painting, setting up of wayfinding and signage systems (Figure 2). Cantiere Mambretti generates a sort of temporary "creative revolution" within the shelters in which all participants can have a voice and bring their help and competences (Campagnaro, Di Prima, \& Ceraolo, 2018). The vibrant atmosphere of the workshop affects the reception service's routines, reverses roles, and creates a positive impact by giving value to participants' skills and aspirations. The effects of this designing together depend on the participants. As regards the experience of immigrants and the homeless, the participation generates their feeling of being active users and recognised

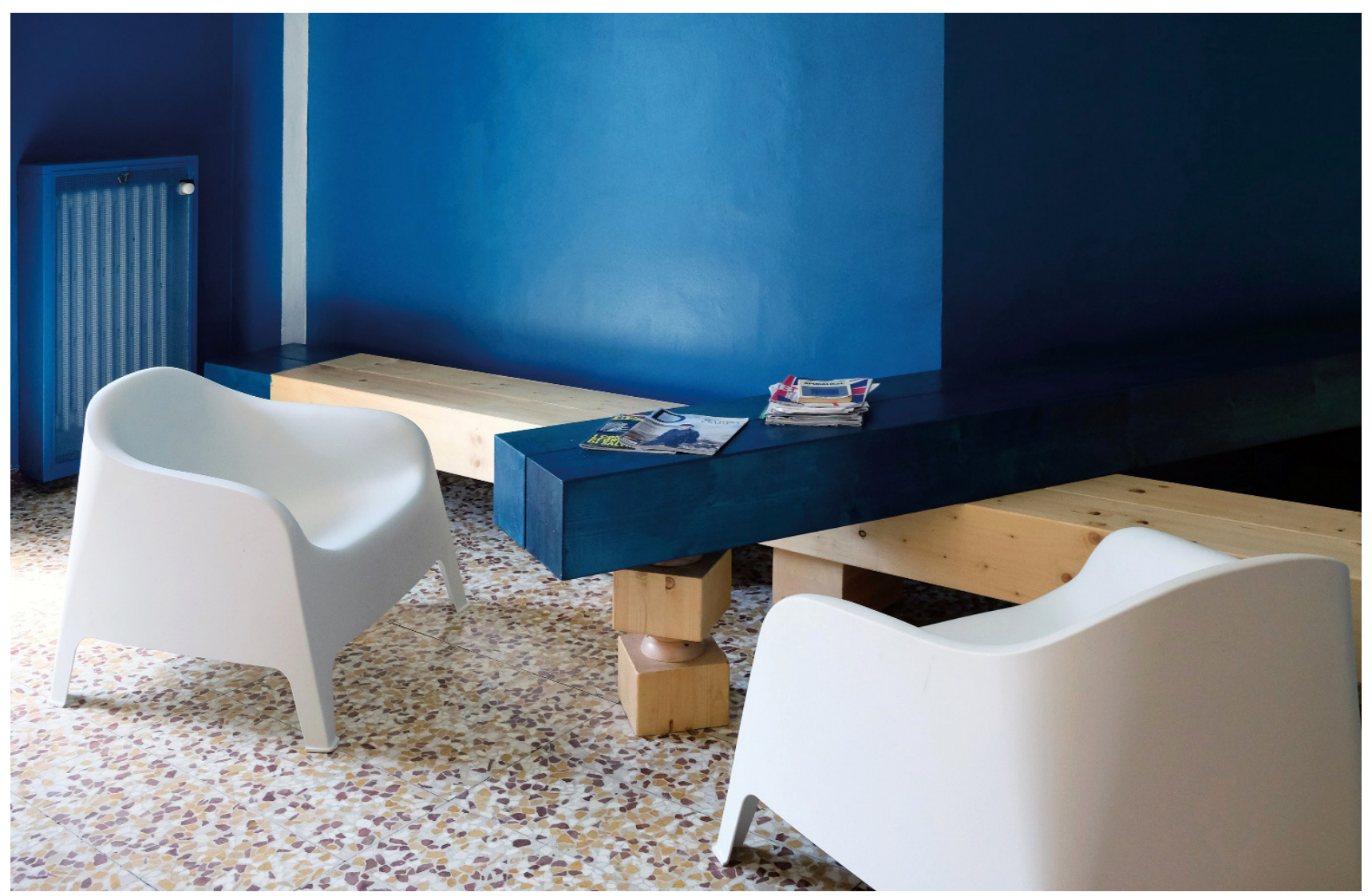

Figure 2. Cartoons corner: A co-designed and co-produced lounge for project Cantiere Mambretti (copyright Daniele Lazzaretto, Lilithphoto). Source: Campagnaro and Di Prima (2018a, p. 15). 
as citizens. On the other hand, the operators have the chance to critically reconsider the way the housing and support service is provided and to figure out how the spaces could contribute to its improvement.

In the case of Cantiere Mambretti, we witnessed an evolution in the organisation's rationale regarding shelters: From "pathogenic and multipliers of suffering" (quoting sociologist Ota De Leonardis, as cited in Camarlinghi, 2020, p. 13) and surroundings that disregard people's need for social and personal recovery, they are now acknowledged as "apparatuses" (Agamben, 2006) useful in relationship building, inclusion, and care. However, although the participatory approach-and the change it fosters in housing services-has been acknowledged and understood by the organisation, it has not been fully adopted as a praxis. In fact, even though there is an ideal consensus on the values promoted by the co-design processes, these have not been transferred to the organisation's decision-making processes regarding other care spaces (decoration, refurbishment, organisation of functions, or rules). Indeed, they are still directed by technicians who are not part of, and experienced with, care processes and who do not give sufficient consideration to users' and frontline workers' experiences and points of view. As researchers, we assume that our participation is still crucial at this stage of collaboration with the organisation; this latter seems as yet unable to manage the co-design process by itself and to apply the participatory approach to all the service's design process, from architecture to living functions, from furniture to rules. Thus, today's challenge of Cantiere Mambretti is to continue to experiment with this new design process, again and again. The aims of the project are to keep alive the idea that shelters are spaces of citizenship and to figure out whether the concrete adoption of this participatory model by the organisation is possible or, on the contrary, if our role is key and cannot be ceded to third parties.

The preliminary hypothesis that we have developed is that participatory projects are much more complex than the organisation's ordinary management capacity and cannot easily be cut off from the coordination of us professionals/researchers. In fact, any project, if it is truly participatory, requires a flexibility and variability of methods, instruments, and results that cannot be foreseen in advance, at least not as far as the organisation would like. In addition, the participatory process requires long periods of time, critical sensitivity, attention, and skills that must be continually experimented, trained, and nourished by research and study; all this seems to us to belong more to the posture of participatory action research than to that of work performance.

\subsection{Costruire Bellezza: Design Anthropology-Led Lab Based in Turin, Aiming at Social Inclusion}

The project Costruire Bellezza ("crafting beauty") was born in 2014, in the framework of a collaboration with the city of Turin. It is a participatory lab that, via creative actions, includes people who are experiencing homelessness, social service assistants, social workers, students, researchers, and creative professionals (Campagnaro, 2021b; Campagnaro et al., 2021; Porcellana, 2019; Stefani, 2016). The project benefits from the design alliance between public services for homeless people, the social cooperative Animazione Valdocco that manages these services, and our university. The lab is based on cycles of workshops carried out every Thursday and Tuesday in a public shelter. Thanks to the lab, every citizen can enter the shelter, which had previously been closed to the city, join the creative group, and participate in workshops (Figure 3). Participants' co-design and co-create artefacts for themselves and for the neighbourhood's communities such as chairs, tables, lamps, outdoor furniture, toys for children, clothes and accessories, wall paintings, and so on.

The collaboration between the participants facilitates the self-empowerment of those experiencing homelessness (Appadurai, 2004) and fosters relational skills of the university students and citizens taking part in the lab (Margolin \& Margolin, 2002). The core value of Costruire Bellezza is reciprocity, which plays its role on two levels: on the level of the creative experience, where the participants share competences, skills, and help one another in order to co-design and co-create products; on the level of the place, where the creative potential of the heterogeneous group generates a learning environment based on doing things together. As far as the social services are concerned, the lab regenerates the shelter as a venue where contact between social workers, social service assistants, and homeless people is facilitated by an atmosphere of beauty, informality, and social justice (Fraser, 1998, 2005). This contrasts with the highly institutionalised offices of social workers, which is where the periodic meetings and monitoring of the progress of the homeless' social recovery project are carried out.

Furthermore, the experience of nine months of each participant in Costruire Bellezza was monitored by the facilitators-both designers and social service assistants - with a focus on interpersonal relationships, the exercise of abilities, and personal wellbeing. According to these three issues, the participants were also asked about their nine months of experience in the project. These parameters of investigation helped to redesign the Costruire Bellezza design initiatives. Moreover, they described each person's feelings in their path toward finding stable accommodation, and they helped case managers to better plan and, in progress, adapt the individual's recovery project.

The investigation is still running through participant observation, focus groups with facilitators, and semi-structured interviews with participants. Results obtained to date suggest that engagement in the creative workshops improves people's personal, cognitive, and social abilities, including self-care in daily routines and life, openness to change, trust in the others and the pairs, capacity to plan, willingness to experiments 


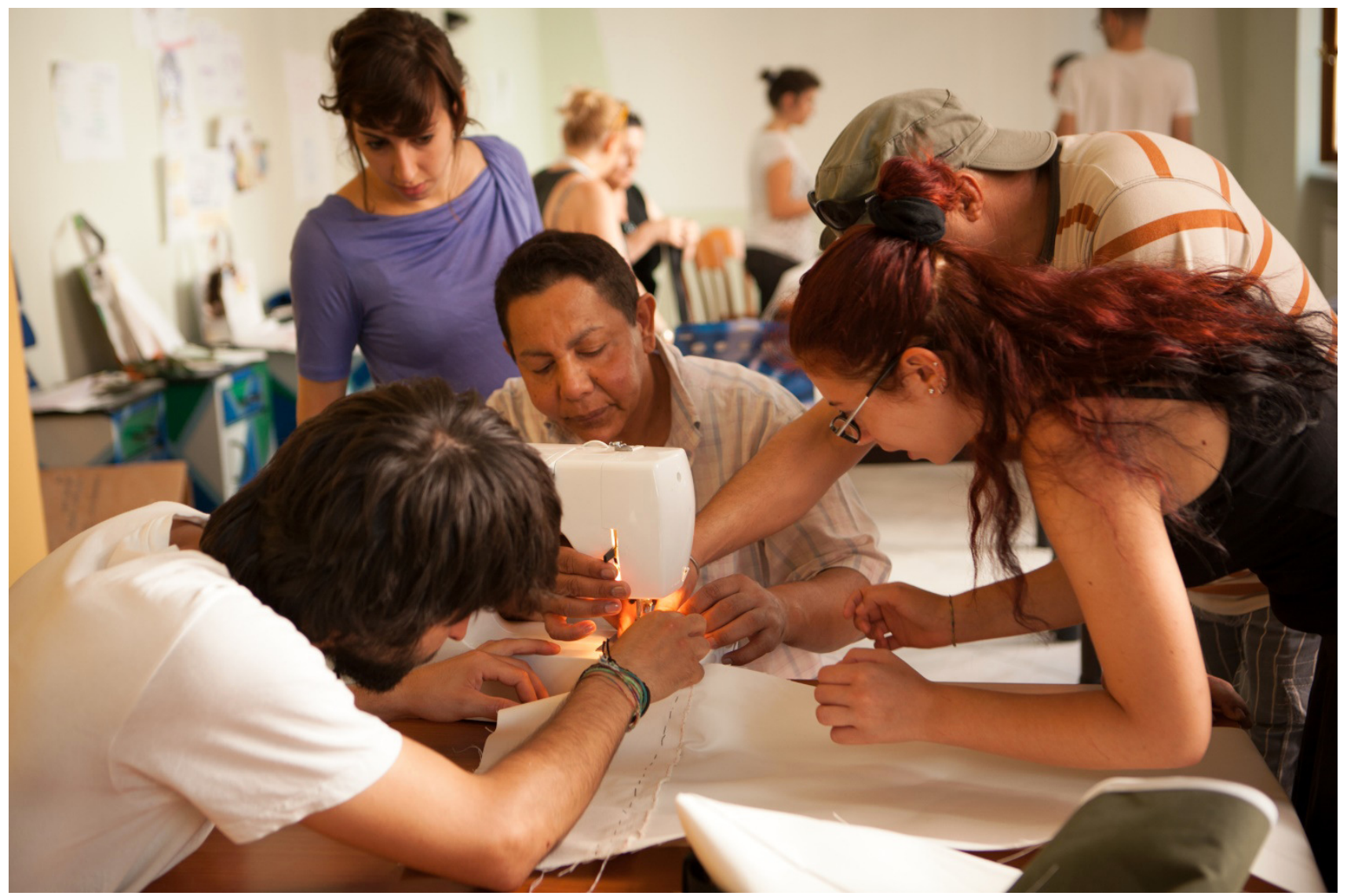

Figure 3. Sewing workshop: Citizens, both experiencing homelessness and otherwise, are sewing together during a "Costruire Bellezza" workshop.

with newness, and new nodes of network releasing from the isolation of homelessness (Campagnaro \& Ceraolo, 2020; Petrova \& Campagnaro, 2017; Porcellana \& Campagnaro, 2019a).

\subsection{PON 18-21: Innovating Services to Innovate Systems for Homeless People}

In 2018, our research group signed an agreement with the Turin municipal administration to promote a process of reorientation of care practices and services for the city homeless community. The aim was to reinforce the care system and foster voice, participation, ease, dignity, and wellbeing for both users and care/frontline workers, as well as social workers. This project is the most complex experience of participatory design that the research group has faced in ten years of work and collaboration with the city of Turin (Campagnaro, 2019). In fact, it involves accompanying an entire system of public, private, and third sector actors-with more than 50 operators from the numerous bodies involved in addressing homelessness in Turin being involved in the participatory service design activities. The project encouraged this set of actors to rethink, in a collective and mutually beneficial way, the organisation of the city system, and the service provision in terms of prevention, inclusion, and recognition.
In the first phase, through various anthropology and co-design tools, a critical and reflective participatory analysis of the service system was carried out during several collective design actions-from mapping the resources to problem framing. These processes used maps, graphs, and qualitative descriptions to re-examine every dimension of the city services system and to highlight areas for incremental and radical improvement: a wider social mission of the service, a more systemic implementation of the city services, new inclusive strategies for care and assistance, new infrastructures for dayto-day actions. In a subsequent phase, a shared vision of change was developed through envisioning, scenario design, and role-playing techniques. Furthermore, we investigated worldwide exemplary case studies that foster collective creative thinking. In general, all actors agreed that the transformation should be more focused on people as bearers of rights and resources. More precisely, the heterogeneous group of diffuse service designers (Manzini, 2015) agreed on five guidelines concerning: methods of support and "taking charge" of individuals by the social services; multiple and more heterogeneous (than today's solutions) housing resources; pathways to social inclusion based on the principle of citizenship and active participation; access to material assets with more attention to the needs of the individuals and avoidance of standardisation; and an approach 
to face homelessness based on primary, secondary, and tertiary prevention (Gaetz \& Dej, 2017).

We gathered-again through on field observation and focus groups-a collective demand for change that involves all the levels of the staircase model (Gaboardi et al., 2019), from the street to the regained home. There is a clear consensus on services that focus more on the capabilities of the individuals experiencing homelessness and those characterised by greater flexibility on entry, during the use, and on egress. However, in redesigning the system and the way it should work, considerable difficulties have also been observed in conceiving radical and systemic transformations that go beyond a progressive and an overly cautious improvement of day-to-day work.

From the point of view of public spaces, this participatory system and service design action offer a vision of a city and its places of care that must become an instrument and "the milieu of the services" (Camarlinghi, 2020, p. 13) and of the works on fragility: Only open places, accessible services, and inclusive policies can foster the exercise of the right to the city as "the right to freedom, individualisation in socialisation, habitat and housing. The right to the work (to participating activity) and the right to enjoyment quite different from the right to property" (Lefebvre, 2014, p. 130). A vision that belies and overturns a present in which, in our experience from a bottom-up perspective, the city more often appears to be the arena of processes of separation and competition between citizens which leaves the most fragile behind. At its worst, the city degenerates into a device of control and containment on the strength of paternalistic cultural models and power relationships (Campagnaro, 2021a).

\section{Designerly Ways of Facing Complexity}

The case studies we have discussed so far deal with the application of the co-design method to develop tangible and intangible artefacts together with the users: an aid, a place, a new social service, a process of systemic innovation. Jones and VanPatter's (2009) theory of design domains (DD) highlights the different degrees of complexity of each project. Nevertheless, despite this difference, they all sought to transform "their systems" through specific and participated interventions in which the places where we design are crucial. From the perspective of our action research, these projects and interventions also worked as a "can opener" (Collier \& Collier, 1986), allowing us to enter the systems, explore them, and investigate the complexity of the social relationships and bonds the co-design process ignited.

In the project Design for Each(One), the focus is on the product (DD 1.0). The impact is certainly connected to how good the aids are in coping with the personal needs of each individual user. But the participatory processes of design also proved able to empower the organisation system, strengthen the educational and relational work, and open up and "fill" the care centre with cre- ativity and a stronger sense of active citizenship which, according to Meer and Sever (2004, p. 11):

In addition to being about a status that confers rights and obligations, citizenship is also a practice whereby people are able to participate in shaping their societies. It implies not only rights and responsibilities, but also interaction and influence within the community.

In Cantiere Mambretti, the participatory renovation of the shelter suggests that undertaking a design process, that stems advantage of the redesign of places through furniture and wayfinding tools (DD 1.0), provides an opportunity to address the more complex scales of service design (DD 2.0) and organisational innovation (DD 3.0). According to our perspective, the fact that we adopted the co-design model as a new way to do things solicited the improvement of the whole housing service; in fact, the co-design practice promoted not only worthwhile physical changes but also innovation in the strategy that led the service, toward a more user- and operatorsensitive and attentive care perspective.

Regarding the case of Costruire Bellezza, we are in the framework of the high complexity of organisational transformation (DD 3.0). It entered a place of exclusion through acts of collective creativity, which it opened and nourished via citizens' participation, thanks to meaningful encounters. It innovated how people engage in dialogue with other citizens and social and health care services. Furthermore, it implemented a shift from an institutionalised approach, according to which people experiencing poverty are responsible for their situation, to a community-based model, where they are citizens with rights and capacities. It began as an experiment (Binder \& Redström, 2006) in 2014, and today it continues as one of the public services for the Turin homeless population. Nevertheless, from the point of view of social cohesion, Costruire Bellezza is an example of how place-based co-design processes can solicit the innovation of services and policy models (DD 4.0).

PON 18-21, dealing with the innovation of systems and policies (DD 4.0) in support of the homeless population in Turin, shows how interconnected and interdependent the four design domains are. It is an innovation that must be pursued through the simultaneous implementation of new tools, new processes, new places, as well as a new vision of our society (DDs 1.0, 2.0, 3.0). Both the public and the private sectors should use them to support people in poverty toward a new "public happiness" (Ravazzini \& Saraceno, 2012). Quoting Tronto (2013), we can regard PON 18-21 as a collective-final users included-attempt to promote a democracy of care that includes the recognition of homeless people needs (caring about), the assumption of responsibility for meeting those needs (caring for), the care provided for those in need (caregiving), and finally the responses of beneficiaries towards the care received (care-receiving). 


\section{Conclusion}

An attribute of all the processes that we have presented previously is that they have two dimensions of meaning. The first deals with the transformations that they implement in response to specific problems, while the second deals with how these transformations are functional to an attentive process of reading and decoding reality. These are two mutually useful dimensions of design that are intertwined in time and are the core of our design anthropology method (Campagnaro et al., 2021; Gunn, \& Donovan, 2012; Porcellana \& Campagnaro, 2019b; Porcellana et al., 2017). While it is true that projects are the result of careful, intensive, and non-judgmental listening and observation, it is equally true that further knowledge of the individuals, as well as the system, its limits, and its resources, can be deduced through an equally attentive and participant observation (Ingold, 2013) of the process of development and implementation of design ideas. In addition, we can state that experiencing co-design entails a plurality of collective processes such as knowing, learning, teaching, sharing, and creating (Cross, 1982; Manzini, 2015; Verganti, 2009). It can also promote values that designers and individuals from non-creative occupations can share, and it increases the individuals' motivation to collaborate and pursue common interests and benefits.

In order to enable citizens and the system to participate in the innovation process, every stakeholder needs to be aware of the resources that they can provide to the system. The resources are different, depending on each individual and their network. Resources consist of abilities, such as knowledge, experiences, technical skills, and aspirations, as well as opinions, preferences, and desires. These resources and individuals' capacity to aspire can be increased through practise, exploration, conjecture, and rejection, and also by the opportunity to exercise one's voice, to debate, challenge, investigate, and participate critically (Appadurai, 2004, p. 67). Collective and participatory situations offer the strongest chance of facilitating the creation of new relationships and connections between actors, with the aim of sharing their own resources.

Furthermore, thanks to participatory processes, the aspirations of the system are raised, which could be the beginning of a process of change that might also impact the regulatory and policy context in which the action takes place, enabling innovation to be embedded on any level: individual, social, societal, and transcendental (Klamer, 2017). Since this process is difficult because it entails comprehending a high level of complexity, working together on a specific and concrete product can be enabling. These co-designs and collective creativity, focused on tangible outputs, are effective in developing an understanding of the problems that everyone shares and sets of possible solutions which everyone agrees on. In fact, the intuitions and proposals from both researchers and groups can be seized as opportunities only if the system recognises them as such. Nevertheless, new visions of the services also depend on a move away from the usual roles and relationships-the operators that assist or help people in need-toward a system as an organic entity where everyone is a beneficiary of other's resources. As already stated, this is a shift strongly rooted in new roles and the extraordinary work that the participatory process and co-creation workshops entail.

Regarding the issue of spaces, the design initiatives brought the creative process among the very people's environments: into day centres, into housing shelters, and into the city-wide services. We preferred informal design conditions, something like Oldenburg's (1989) "third place", in order to facilitate the communities of practice to meet (Wenger, 1998) and to foster the audience engagement and knowledge exchange. It was a matter of working in "imperfect places" from the perspective of a space for academic design; this choice had the merit of not inhibiting the beneficiaries and allowed the research team and the designers to collaborate with and observe them in their everyday situations, behaviours, and relationships. This expands the idea of the places of innovation towards forms of hospitality and greater openness to the whole city. The comparison between different life stories and cultural repertoires, the combination of which is one of the keys to a collective creative process, transformed all these ordinary work and care spaces into learning environments (Sichula et al., 2016) and powerful activated devices for change (Cautela \& Zurlo, 2006, p. 56).

These places are meant as public because they are dedicated to the citizens; but, in our case, since they are places for people in conditions of fragility and marginality, we experienced them as Foucault's "crisis" or "deviation" heterotrophies (Foucault, 2011, pp. 24-32; Foucault \& Miskowiec, 1986). Here, the aim is to provide protection and privacy that is owed to persons experiencing fragility, and so they are closed to all other citizens; one cannot enter unless they recognise themselves as needing protection and care. However, in our experience, in being so protective, they subtract people from the relationship with the other citizens, from reciprocal discovery, and tend to expose people to stereotypes, clichés, and judging gazes.

On the contrary, our projects and the experiences they promote, stimulate, and produce sociality and enable the exercise of "civility" (Bauman, 2001) and respect for the other, directly within the places where people experience their everyday lives. In this exercise of openness, our actions solicit the public dimension of the spaces in which the designing takes place (Robbins, 2008), where people interact (Arendt, 1958), where they think about collective interest and enhance individual cultures in the encounter (Innerarity, 2006). At the same time, in our experience, these spaces, even the very city, play different roles: They are the object of the projects, opening up and transforming definitively or momentarily; they are the apparatuses (Agamben, 2006) 
of co-design and active citizenship processes (Meer \& Sever, 2004, p. 11); they significantly affect the processes and foster, or on the contrary deny, the creative relationships between the participants and between the design systems' stakeholders.

So, it happens that these places are no longer the same after crossing the co-design process because those extraordinary events contributed to favourably expanding the perception of them towards new possibilities and new uses. In the perception of every citizen, now, they also can be seen as laboratories of co-design and co-creation, as open today as they were closed and reserved only for service users in the past. The sounds change, a frenetic hubbub and a dense and collaborative dialogue replace the silences and noises of routine. The movements, the use of timetables, and the very perception that people have of their own place give way to the extraordinary vitality of a heterogeneous community that plans, experiments, fails, and succeeds together. Today, these are places that anyone can enter or where people can meet other citizens and cooperate with them. They became sites of innovation, creativity, learning, and knowledge transmission. This fosters cohesion and inclusiveness and generates the opportunity for all those involved to flourish, and likewise, the same can happen to the locations where these communities exist.

In conclusion, regarding us designers, these experiences lead us to believe that our participant role is pivotal in the participatory processes, maybe inalienable, and must be maintained. Indeed, as stated by Manzini (2015, p. 204), expert design "day by day and issue by issue... sustains social actors in the constant co-designing process in which we find ourselves... works as a cultural operator, collaborating in the creation of the shared images and stories that underlie a new idea of wellbeing." Accordingly, we must solicit and facilitate transformative and critical thinking, innovation, and experimentation, by designing with citizens, both users and staff. That is why we need places that are open and accessible to everyone, which make it possible to co-design by mediating between the extraordinary of the design initiatives and the ordinary of life and work. In our opinion, and according to our research findings, only there, among people, within people's environment, can we keep being those "agents of change who apply their skills to creatively and playfully diagnose problems, question the status quo, and propose new directions for change" (Minder \& Lassen, 2008, p. 174).

\section{Acknowledgments}

Thanks to the Municipality of Turin, to Fondazione Progetto Arca, and to cooperative Animazione Valdocco for supporting the projects. Thanks to all the people with whom we have designed together. We shared much of the research path on homelessness with our friend, ally, and teacher, the anthropologist Valentina Porcellana. The PON 18-21 research was carried out in collaboration with Prof. Antonella Meo, Silvia Stefani, Daniela Leonardi, Vittoria Bosso, Emilia D'orazio, and Giorgia Curtabbi.

\section{Conflict of Interests}

The authors declare no conflict of interest.

\section{References}

Agamben, G. (2006). Che cos'è un dispositivo? [What is an apparatus?]. Nottetempo.

Appadurai, A. (2004). The capacity to aspire: Culture and the terms of recognition. In V. Rao \& M. Walton (Eds.) Culture and public action (pp. 59-85). Stanford University Press.

Arendt, H. (1958). The human condition. University of Chicago Press.

Arnstein, S. R. (2019). A ladder of citizen participation. Journal of the American Planning Association, 85(1), 24-34.

Banham, R. (1972). Alternative networks for the alternative culture? In Design participation: Proceedings of the design research society's conference (pp. 15-18). Design Research Society.

Bauman, Z. (2001). The individualized society. Polity Press.

Binder, T., \& Redström, J. (2006). Exemplary design research [Paper presentation]. DRS Wonderground Conference, Lisbon, Portugal.

Bourriaud, N. (2010). La forma relazionale [The relational form]. In N. Bourriaud (Ed.). Estetica relazionale [Relational aesthetics] (pp. 11-24). Postmedia Srl.

Brandolini, A., Saraceno, C., \& Schizzerotto, A. (2009). Dimensioni della disuguaglianza in Italia: Povertà, salute e abitazione [Dimensions of inequality in Italy: Poverty, health and housing]. II Mulino.

Brause, C. (2014). Prototyping practice. Illinois Institute of Technology College of Architecture. http://works. bepress.com/caryn_brause/3

Bruni, L. (2008). Back to Aristotle? Happines, eudaimonia and relational goods. In L. Bruni, F. Comim, \& M. Pugno (Eds.), Capabilities and happiness (pp. 114-129). Oxford University Press.

Camarlinghi, R. (2020). Se i diritti sono come l'aria e l'acqua [If rights are like air and water]. Animazione Sociale, 5(337), 6-16.

Campagnaro, C. (2019). Homelessness: Esperienze di co-design e case di housing first [Homelessness: Co-design experiences and housing first homes]. Atti e Rassegna Tecnica, 83, 82-88.

Campagnaro, C. (2021a). Città coese e inclusive [Cohesive and inclusive cities]. In E. Formia, V. Gianfrate, \& E. Vai (Eds.), Design e mutazioni. Processi per la trasformazione continua della città [Design and mutations. Processes for the continuous transformation of the city] (pp. 233-247). Bononia University Press.

Campagnaro, C. (2021b). Crafting beauty together. In 
S. Gonçalves \& S. Majhanovich (Eds.), Art in diverse social settings (pp. 185-196). Emerald Publishing Limited.

Campagnaro, C., \& Ceraolo, S. (2020). D tutt*. Esperienze di empowerment femminile in Costruire Bellezza [D tutt*. Female empowerment experiences in Crafting Beauty]. In G. Di Bucchianico, R. Fagnoni, L. Pietroni, D. Piscitelli, \& R. Riccini (Eds.), 100 anni dal Bauhaus. Le prospettive della ricerca in Design [100 years since the Bauhaus. The perspectives of research in design] (pp. 59-65). Società Italiana di Design.

Campagnaro, C., \& Di Prima, N. (Eds.). (2018a). Disegnare ambienti che accolgono [Designing places that welcome]. VITA Società Editoriale.

Campagnaro, C., \& Di Prima, N. (2018b). Empowering actions. The participatory renovation of a shelter. Interventions/Adaptive Reuse, 9, 68-75.

Campagnaro, C., Di Prima, N., \& Ceraolo, S. (2018). Insieme. Collaborazioni Inclusive [Together. Inclusive collaborations]. In C. Campagnaro \& N. Di Prima (Eds.), Disegnare ambienti che accolgono [Designing places that welcome] (pp. 24-25). VITA Società Editoriale.

Campagnaro, C., Di Prima, N., Porcellana, V., \& Stefani, S. (2021). La palestra delle cose [Triggering things]. DIID: Disegno industriale industrial design, 70, 88-95.

Campagnaro, C., \& Giordano, R. (2017). Home for homeless: Linee guida per la progettazione dei centri di accoglienza notturna [Homes for homeless: Design guidelines for night shelters]. Techne, 14, 179-187.

Campagnaro, C., \& Porcellana, V. (2016). Beauty, participation and inclusion: designing with homeless people. In S. Gonçalves \& S. Majhanovich (Eds.), Art and Intercultural Dialogue (pp. 217-231). Sense Publishers.

Campagnaro, C., Porcellana, V., Stefanizzi, A., \& Ceraolo, S. (2018). Oggetti, spazi, persone: Osservare e valutare le sperimentazioni con un approccio di design anthropology [Objects, spaces, people: Observing and evaluating the experiments with a design anthropology approach]. In P. Molinari \& A. Zenarolla (Eds.), Prima la casa. La sperimentazione Housing First in Italia (pp. 178-194). FrancoAngeli.

Carlile, P. (2002). A pragmatic view of knowledge and boundaries: Boundary objects in new product development. Organization Science, 13(4), 442-445.

Cautela, C., \& Zurlo, F. (2006). Relazioni produttive. Design e strategia nell'impresa contemporanea [Productive relationships. Design and strategy in contemporary business]. Aracne.

Cockersell, P. (2014). St Mungo's e il progetto Safya [St Mungo's and the Safya project]. In M. Castaldo, A. Filoni, \& I. Punzi (Eds.), Safya. Un approccio transdisciplinare alla salute degli homeless in Europa [Safya. A transdisciplinary approach to the health of the homeless in Europe] (pp. 67-87). FrancoAngeli.

Collier, J., \& Collier, M. (1986). Visual anthropology: Pho- tography as a research method. University of New Mexico Press.

Cross, N. (1982). Designerly ways of knowing. Design Studies, 3(4), 221-227.

Dreyfuss, H. (1955). Designing for people. Simon and Schuster.

fio.PSD. (2016). Linee di indirizzo per il contrasto alla grave emarginazione adulta in Italia [Guidelines for combating serious adult marginalization in Italy]. http://www.fiopsd.org/wp-content/uploads/ 2016/04/linee_indirizzo.pdf

Foucault, M. (2011). Spazi altri [Other spaces]. Mimesis.

Foucault, M., \& Miskowiec, J. (1986). Of other spaces. Diacritics, 16(1), 22-27.

Fraser, N. (1998). Social justice in the age of identity politics: Redistribution, recognition, participation (WZB Discussion Paper, No. FS I 98-108). WZB Berlin Social Science Center. http://hdl.handle.net/10419/44061

Fraser, N. (2005). Reframing justice in a globalizing world. New Left Review, 36, 1-19.

Gaboardi, M., Lenzi, M., Disperati, F., Santinello, M., Vieno, A., Tinland, A., Vargas-Moniz, M. J., Spinnewijn, F., O'Shaughnessy, B. R., Wolf, J. R., Bokszczanin, A., Bernad, R., Beijer, U., Ornelas, J., Shinn, M., \& HOME-EU Consortium Study Group. (2019). Goals and principles of providers working with people experiencing homelessness: A comparison between Housing First and traditional staircase services in eight European countries. International Journal of Environmental Research and Public Health, 16(9). https://www.mdpi.com/1660-4601/ 16/9/1590/htm

Gaetz, S., \& Dej, E. (2017). A new direction: A framework for homelessness prevention. Canadian Observatory on Homelessness Press.

Gunn, W., \& Donovan, J. (2012). Design and anthropology: An introduction. In J. Donovan \& W. Gunn (Eds), Design and anthropology (pp. 1-16). Ashgate.

Hillgren, P., Seravalli, A., \& Emilson, A. (2011). Prototyping and infrastructuring in design for social innovation. CoDesign, 7(3/4), 169-183.

Ingold, T. (2013). Making, Anthropology, archaeology, art and architecture. Routledge.

Innerarity, D. (2006). El nuevo espacio público [The new public space]. Espasa

Jones, P. H., \& VanPatter, G. K. (2009).Understanding Design 1.0, 2.0, 3.0, 4.0: The rise of visual sensemaking [Special Issue]. NextD Journal, 3. https://issuu. com/nextd/docs/understandingdesign1_2_3_4

Klamer, A. (2017). Doing the right things: A value-based economy. Ubiquity Press.

Lee, Y. (2008). Design participation tactics: eChallenges and new roles for designers in the co-design process. CoDesign, 4(1), 31-50.

Lefebvre, H. (2014). Il diritto alla città [The right to the city]. Ombre Corte.

Magni, S. F. (2006). Etica delle capacità. La filosofia pratica di Sen e Nussbaum [Ethics of capabilities. 
The practical philosophy of Sen and Nussbaum]. II Mulino.

Manzini, E. (2015). Design, when everybody designs: An introduction to design for social innovation. MIT Press.

Margolin, V., \& Margolin, S. (2002). A "social model" of design: Issues of practice and research. Design Issues, 18(4), 22-30.

Mclntyre, A. (2008). Participatory action research. SAGE.

Meer, S., \& Sever, C. (2004). Gender and citizenship: Overview report. University of Sussex, Institute of Development Studies. http://www.jdhr.org/ publications/reports/GENDER\%20and\%20

CITIZENSHIP\%200verview\%20Report.pdf

Meroni, A., Selloni, D., \& Rossi, M. (2018). MASSIVE CODESIGN: A proposal for a collaborative design framework. FrancoAngeli.

Minder, B., \& Lassen, A. H. (2008). The designer as jester: Design practice in innovation contexts through the lens of the Jester Model. She Ji: The Journal of Design, Economics, and Innovation, 4(2). https:// reader.elsevier.com/reader/sd/pii/S2405872618300 029?token=EBC2EFA7FD076832A42A5C4D392700 B2F733528556802CC54B17A712FC2B0A9C1157 A98B13D9BC94B2795F8C3A382B12\&originRegion= eu-west-1\&originCreation $=20210831220536$

Nota, L., \& Soresi, S. (Eds.). (2017). For a manifesto in favour of inclusion. Concerns, ideas, intentions, and passwords for inclusion. https://www.unipd.it/sites/ unipd.it/files/2019/Manifesto_hogrefe.pdf

Oldenburg, R. (1989). Celebrating the third place: Inspiring stories about the great good places at the heart of our communities. Marlowe \& Company.

Papanek, V. (1971). Design for the real world: Human ecology and social change. Pantheon Books.

Passaro, R., Campagnaro, C., \& Curtabbi, G. (2021). Design against food poverty. Revista Latinoamericana De Food Design, 1(2), 426-451.

Petrova, L., \& Campagnaro, C. (2017). Design for social change: On new practices and organization models that foster knowledge transfers from design sector elsewhere. In Proceedings of relating systems thinking and design (RSD6) 2017 symposium. Systemic Design Research Network. https://iris.polito. it/retrieve/handle/11583/2705354/194197/2017_

SystemDesign_working_paper_Campagnaro_ Petrova.pdf

Porcellana, V., Campagnaro, C., \& Di Prima, N. (2020). Weaving: Methods and tools against homelessness between anthropology and design. Antropologia, 7, 63-82.

Porcellana, V. (2019). Costruire Bellezza: Antropologia di un progetto partecipativo [Costruire Bellezza: Anthropology of a participatory project]. Meltemi.

Porcellana, V., \& Campagnaro, C. (2018). Dalla strada alla casa. Oggetti e spazi domestici nei percorsi di inserimento abitativo di persone senza dimora [From the street to the house. Domestic objects and spaces in the home integration paths of homeless people]. Lares, 79, 265-283.

Porcellana, V., \& Campagnaro, C. (2019a). Antropologia trasformativa e design di sistema alla prova delle povertà urbane più estreme [Transformative anthropology and system design to the test of the most extreme urban poverty]. In T. Ciampolini (Ed.), Comunità che innovano. Prospettive ed esperienze per territori inclusivi [Communities that innovate. Perspectives and experiences for inclusive territories] (pp. 193-205). FrancoAngeli.

Porcellana, V., \& Campagnaro, C. (2019b). Progettare insieme [Designing together]. Antropologia Pubblica, 5, 91-110.

Porcellana, V., Campagnaro, C., \& Di Prima, N. (2017). Quando l'antropologia incontra il design. Riflessioni a margine di una ricerca-azione a contrasto dell' homelessness [When anthropology meets design. Reflections on the sidelines of an action-research in contrast to homelessness]. Illuminazioni, 42, 229-251.

Ravazzini, M., \& Saraceno, B. (Eds.). Le sfide della felicità urbana [The challenges of urban happiness]. II Saggiatore.

Robbins, E. (2008). Rethinking public space: A new lexicon for design. Urbani Izziv, 19(2), 140-146.

Schumacher, E. F. (1973). Small is beautiful. Harper \& Row.

Sen, A. (2008). The economics of happiness and capability. In L. Bruni, F. Comim, \& M. Pugno, (Eds.), Capabilities and happiness (pp. 16-27). Oxford University Press.

Sennet, R. (2012). Together: The rituals, pleasures, and politics of cooperation. Yale University Press.

Sichula, N. C., Wanga, W. C., \& Phyllis, I. S. (2016). The adult learning environment. Journal of Adult Education, 2(2), 14-21.

Smithsonian Institute. (2013). Design and social impact: A cross-sectoral agenda for design education, research and practice. The Smithsonian's Cooper-Hewitt and National Design Museum. http:// www.cooperhewitt.org/publications/design-andsocial-impact

Star, S. (2010). This is not a boundary object: Reflections on the origin of a concept. Science, Technology, \& Human Values, 35(5), 601-617.

Stefani, S. (2016). Antropologia in azione. Etnografia di un laboratorio partecipativo [Anthropology in action. Ethnography of a participatory laboratory]. In V. Porcellana \& S. Stefani (Eds.), Processi partecipativi $e$ etnografia collaborativa nelle Alpi e altrove [Participatory processes and collaborative ethnography in the Alps and elsewhere] (pp. 169-194). Edizioni dell'Orso.

The Care Collective. (2020). The care manifesto. The politics of interdependence. Verso Books.

Tronto, J. C. (2013). Caring democracy: Markets, equality, and justice. New York University Press.

Verganti, R. (2009). Design-driven innovation. Changing 
the rules of competition by radically innovating what things mean. Harvard Business Press.
Wenger, E. (1998). Communities of practice: Learning, meaning, and identity. Cambridge University Press.

\section{About the Authors}

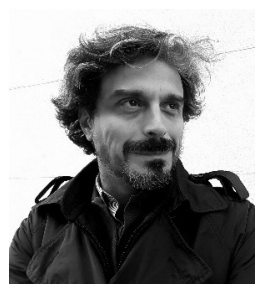

Cristian Campagnaro (PhD) is architect and an associate professor at the Department of Architecture and Design, Politecnico di Torino. There, he teaches scenario design, design for social impact, and design for interior architecture. He taught industrialisation design for social inclusion at ECAM university in Lyon. ADI DESIGN INDEX selected in the field of social design, thanks to designs on homelessness, motor disability, circular economy, and food poverty, he focuses his research both on design for sustainability and design for social inclusion.
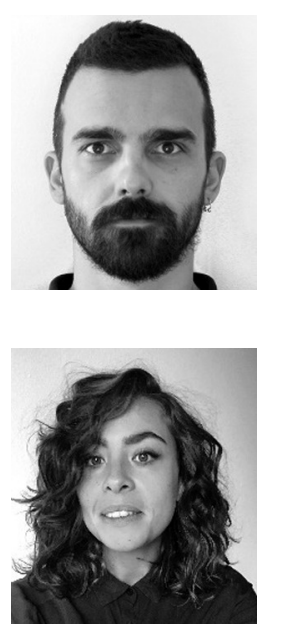

Sara Ceraolo is a designer and sociologist. Since 2015 she has been carrying out research and teaching activities at the Department of Architecture and Design, Politecnico di Torino. Her work focuses on co-design, participatory processes, social inclusion, housing, community engagement, and socially responsible design processes addressing food waste. 